\title{
SUBSTITUSI TEPUNG KULIT PISANG KEPOK PADA PEMBUATAN CAKE PISANG DITINJAU DARI SIFAT FISIK DAN TINGKAT KESUKAAN
}

\author{
Inten Ihromi May, Risa Panti Ariani, Cokorda Istri Raka Marsiti. \\ Jurusan Pendidikan Kesejahteraan Keluarga \\ Universitas Pendidikan Ganesha \\ Singaraja, Indonesia \\ e-mail : intanihromi0805@gmail.com, risa.panti@undiksha.ac.id, \\ raka.marsiti@undiksha.ac.id
}

\begin{abstract}
Abstrak
Penelitian eksperimen ini bertujuan untuk mengetahui (1) kualitas cake kulit pisang kepok ditinjau dari sifat fisik adapun sifat yang dimaksud terdiri dari aroma, tekstur dan rasa. Panelis untuk uji kualitas ini menggunakan 7 panelis terlatih yang terdiri dari dosen PKK, (2) untuk mengetahui tingkat kesukaan terhadap cake kulit pisang kepok dalam uji kesukaan ini menggunakan panelis tidak terlatih berjumlah 30 orang yang terdiri dari mahasiswa dan mahasiswi di lingkungan Fakultas Teknik dan Kejuruan. Metode pengumpulan data untuk uji kualitas yang digunakan dalam penelitian ini yaitu metode observasi dengan menggunakan instrumen 1 berupa lembar uji kualitas uji organoleptik dengan 5 skala atau tingkatan yaitu sangat baik, baik, cukup baik, kurang baik, dan sangat kurang baik, dan instrumen 2 uji kesukaan menggunakan uji organoleptik metode yang digunakan yaitu metode observasi dengan menggunakan lembar uji organoleptik dengan 5 skala atau tingkatan yaitu sangat suka, suka, cukup suka, tidak suka dan sangat tidak suka.
\end{abstract}

Kata Kunci : Cake pisang, Sifat fisik, Tingkat Kesukaan, Kulit pisang Kepok.

\begin{abstract}
This experimental research is aimed to know (1) the quality of kepok banana peel cake is seen from physical characters, while the characteristics are consists of aroma, texture and flavour. This quality testing uses 7 trained panelists, consisting of Family Educational Welfare (PKK) lecturers, (2) to find out the level of preference for kepok banana peel cake, in this case, the test is using 30 untrained panelists consisting of 30 students in the Faculty of Engineering and Vocational. The method of collecting data for the quality testing used in this research is observation method by using two instruments, which are: first is in the form of a good organoleptic test with 5 scales or standards namely very good, good, good enough, not good, and very poor. Second instrument is by using the organoleptic test method, the observation method is used with an organoleptic test sheet with 5 scales or levels, namely very like, quite like, like, dislike and really dislike.
\end{abstract}

Keywords: Banana cake, Physical character, standard of likes, kepok banana Peel. 


\section{PENDAHULUAN}

Kabupaten Buleleng sangat kaya akan alamnya. Banyak masyarakat yang memiliki penghasilan dari pertanian dan perkebunan buah local salah satunya yaitu pisang kepok.Pisang kepok (Musa paradisiaca Linn) adalah tanaman buah yang berasal dari kawasan Asia Tenggara (termasuk Indonesia). Pisang kepok merupakan jenis buah yang paling umum ditemui tidak hanya di perkotaan tetapi sampai ke pelosok desa. Buah pisang kepok merupakan buah yang sangat bermanfaat bagi kehidupan manusia, yang dapat dikonsumsi kapan saja dan pada segala tingkatan usia. Pisang kepok dapat digunakan sebagai alternatif pangan pokok karena mengandung karbohidrat yang tinggi, sehingga dapat menggantikan sebagian konsumsi beras dan terigu.

Kulit pisang kepok merupakan bahan buangan (limbah buah pisang) yang cukup banyak jumlahnya.Pada umumnya kulit pisang belum dimanfaatkan secara nyata, hanya dibuang sebagai limbah organik saja atau digunakan sebagai makanan ternak seperti babi, kambing, sapi, dan kerbau. Jumlah kulit pisang yang cukup banyak akan memiliki nilai jual yang menguntungkan apabila bisa dimanfaatkan sebagai bahan baku makanan (Susanti, 2006). Limbah kulit pisang kepok mengandung zat gizi yang cukup tinggi terutama pada vitamin dan mineralnya sehingga dapat dimanfaatkan menjadi beberapa hidangan salah satunya yaitu dengan cara diolah menjadi tepung. Selain dimanfaatkan sebagai tepung, tepung kulit pisang kepok juga dapat memperbaiki kandungan gizi bila diolah menjadi makanan.Kandungan unsur gizi kulit pisang kepok cukup lengkap, seperti karbohidrat, lemak, protein, kalsium, fosfor, zat besi, vitamin B, vitamin $\mathrm{C}$ dan air.Unsur-unsur gizi inilah yang dapat digunakan sebagai sumber energi dan antibodi bagi tubuh manusia (Munadjim, 1988). Dilihat dari kandungan mineralnya kulit pisang kepok mengandung kalsium yang cukup tinggi yaitu sebesar 715 $\mathrm{mg} / 100 \mathrm{~g}$. Melihat kenyataan tersebut, maka harus dicari solusi untuk menangani limbah kulit pisang kepok tersebut. Salah satu solusi yang dapat dilakukan adalah dengan memanfaatkan dan mengolah limbah kulit pisang kepok tersebut lebih lanjut menjadi suatu bahan yang bermanfaat misalnya dibuat tepung kulit pisang kepok untuk bahan substitusi dalam pembuatan cake.

Berdasarkan observasi awal yang telah dilakukan pada penjual gorengan disekitar kota Singaraja yang mengolah olahan pisang kepok berjumlah 5 pedagang. Dari observasi dan wawancara diketahui bahwa para pedagan tersebut masing-masing menghabiskan 4 hingga 5 sisir pisang kepok dalam 1 hari adapun makanan yang dibuat menggunakan buah pisang kepok yaitu pisang goreng, pisang molen dan crepes. Hal ini menunjukkan bahwa kulit pisang yang terbuang kurang lebih 4 hingga 5 sisir setiap hari dari masing-masing pedagang. Limbah kulit pisang kepok akan bertambah banyak pada saat hari libur karena ramai pembeli, jumlah limbah kulit pisang kepok yang banyak merupakan suatu potensi yang bisa dimanfaatkan baik untuk menunjang ekonomi maupun memperkaya jenis pengolahan pangan. Dengan dasar pemikiran ini peneliti membuat tepung dengan limbah kulit pisang kepok sebagai tambahan tepung pada pembuatan cake pisang. Penelitian ini bertujuan untuk mengetahui kemampuan limbah kulit pisang kepok (Musa paradisiaca Linn) menjadi bahan substitusi dengan tepung terigu dalam pembuatan cake pisang.

Tabel 1.

Kandungan bahan pangan tepung kulit pisang kepok dan tepung protein rendah per 100 gram

\begin{tabular}{lcc}
\hline $\begin{array}{c}\text { Kandungan } \\
\text { bahan pangan }\end{array}$ & $\begin{array}{l}\text { Jepung } \\
\text { Kulit } \\
\text { Pisang } \\
\text { Kepok }\end{array}$ & $\begin{array}{c}\text { Jepung } \\
\text { Tepung } \\
\text { Terigu }\end{array}$ \\
\hline Karbohidrat & 59,11 & 77,3 \\
\hline Air & 11,55 & 12,0 \\
\hline Lemak & 15,99 & 1,3 \\
\hline Protein & 0,88 & 8,9 \\
\hline Kadar abu & 12,45 & - \\
\hline Pati & 1,40 & 24 \\
\hline Vitamin C (mg) & 88,83 & 0 \\
\hline Kalori (kkal) & - & 365 \\
\hline
\end{tabular}

(Sumber : Unit Layanan Lab FTP Universitas Udayana 2016) 
Berdasarkan tabel 1.1 tepung kulit pisang memiliki kandungan karbohidrat sebesar $59,11 \%$, air sebesar $11,55 \%$, lemak sebesar $15,99 \%$, protein sebesar $0.88 \%$, kadar abu $12,45 \%$, pati sebesar $1,40 \%$ dan vitamin C sebesar $88,83 \mathrm{mg}$. Sedangkan tepung terigu protein rendah memiliki kandungan karbohidrat sebesar $77,3 \%$, air sebesar $12,0 \%$, lemak sebesar $1,3 \%$, protein sebesar $8,9 \%$, pati sebesar 24\%, vitamin C 0 dan kalori sebesar 365 kkal.

Menurut hasil uji laboraturium tepung kulit pisang kepok memiliki kandungan amilum atau pati sebesar $1,40 \%$. Pati adalah bahan utama penyusun tepung dan memiliki fungsi untuk membentuk kerangka dasar pada kue.Berdasarkan hal tersebut maka tepung kulit pisang kepok dapat digunakan sebagai substitusi tepung terigu.Akan tetapi tidak dapat mengganti sepenuhnya tepung terigu karna perbedaan kandungan pati yang dimiliki oleh tepung kulit pisang kepok tidak terlalu besar bila dibandingkan dengan tepung terigu.

Cake pisang adalah kue yang disiapkan menggunakan pisang sebagai bahan utama dan bahan kue khas ini dapat disiapkan dengan berbagai cara, seperti kue lapis, seperti muffin dan kue mangkuk cake pisang ini dapat ditemukan dalam hidangan Cina, Indonesia, dan Vietnam. Dalam pra eksperimen yang telah dilakukan peneliti telah mencoba 3 formulasi, formulasi pertama yang telah dicoba yaitu $75 \%$ dan kedua $65 \%$ dan ketiga yaitu $50 \%$ dengan hasil yang berbeda sehingga formulasi yang peneliti pilih yaitu menggunakan perbandingan 1:1 atau $50 \%$ untuk tepung terigu protein rendah dan 50\% tepung kulit pisang kepok. Perbandingan ini dipilih karna kandungan pati yang terdapat didalam tepung kulit pisang kepok berbeda dengan kandungan pati yang terkandung pada tepung terigu protein rendah namun kelebihan lain yang terkandung dalam tepung kulit pisang kepok ini adalah kaya akan Vitamin $\mathrm{C}$ dan kandungan lemak yang terkandung dalam tepung kulit pisang kepok tinggi yang nantinya diharapkan dapat mengurangi penggunaan lemak pada pembuatan cake serta kelebihan lain dari cake yang terbuat dari substitusi tepung kulit pisang kepok ini yaitu rendah akan kalori. Dalam pembuatan cake pisang ini buah pisang yang digunakan yaitu buah dari pisang ambon karna buah pisang ambon memiliki rasa yang manis dibandingkan dari buah pisang lainnya yang nantinya dapat mengurangi rasa sepat pada tepung kulit pisang kepok dan tekstur dari buah pisang ambon sangat halus dan lembut saat dihaluskan sebagai salah satu bahan dalam pembuatan cake pisang tersebut.

Beberapa penelitian tentang kulit pisang sudah pernah dilakukan. Adapun penelitian yang menggunakan kulit pisang kepok sebagai penelitian yaitu: pie susu dengan formulasi 1:1, kue semprit dengan formulasi $1: 1$, donat dan brownies yang terbuat dari substitusi kulit pisang kepok. Dalam penelitian ini peneliti memilih membuat produk olahan berupa cake pisang karna ingin menambah kreasi dan inovasi baru terhadap jenis cake yang umumnya hanya terbuat dari tepung terigu saja dengan adanya inovasi cake kulit pisang kepok ini diharapkan dapat dijadikan sebagai alternatif dalam olahan aneka cake dan dapat dijadikan sebagai usaha rumahan karna dapat mengurangi penggunaan tepung terigu sehingga dapat mengurangi biaya dalam pembuatan cake tersebut.

Sifat fisik yang dimaksud dalam penelitian ini meliputi aroma, tekstur, dan rasa pada cake pisang substitusi tepung kulit pisang kepok tersebut.Aroma merupakan hasil respon terhadap suatu produk yang dapat dinilai dari indera penciuman. Tekstur merupakan nilai raba pada suatu permukaan baik itu kasar, halus, lembut dan keras dalam suatu produk, sedangkan rasa merupakan kombinasi mutlak dari dua unsur yaitu rasa dan aroma rasa yang diinginkan harus sejalan dengan aroma yang diinginkan, dan tingkat kesukaan yang dimaksud adalah tanggapan atau respon yang nantinya akan dinilai oleh panelis apakah menyukai cake pisang yang terbuat dari substitusi tepung kulit pisang kepok tersebut. 


\section{METODE}

Metode penelitian adalah teknik atau cara yang digunakan dalam kegiatan penelitian sehingga, pelaksanaan dan hasil penelitian dapat dipertanggung jawabkan secara ilmiah. Penelitian yang digunakan adalah penelitian eksperimen. Penelitian ekperimen merupakan metode penelitian yang paling produktif.Penelitian ini perlu penata laksana yang baik agar dapat menjawab asumsi suatu produk (Sukardi, 2012).Penelitian ini dilakukan melalui percobaan membuat cake pisang dari tepung kulit pisang kepok, sehingga mendapatkan hasil cake pisang yang sesuai dengan kreteria.

Proses pembuatan cake pisang ini menggunakan perbandingan tepung terigu $50 \%$ dan tepung kulit pisang kepok $50 \%$. Desain penelitian yang digunakan dalam penelitian ini adalah The One Shot Case Study, yaitu perlakuan yang diberikan terhadap suatu kelompok selanjutnya dilakukan pengambilan data. Dalam penelitian ini terdapat suatu kelompok diberi treatment (perlakuan) dan selanjutnya diberikan observasi hasilnya.Pembuatan cake pisang ini dilakukan dengan mensubstitusi bahan utama.Tepung kulit pisang kepok sebagai bahan substitusi tepung terigu menggunakan perbandingan $50 \%$ dan $50 \%$.Adapun tahapan dalam eksperimen ini adalah (1) tahap persiapan bahan (2) persiapan alat (3) tahap pengolahan.

Subjek pada penelitian menggunakan panelis terlatih dan tidak terlatih subjek untuk uji kualitas cake kulit pisang kepok berjumlah 7 orang panelis terlatih karna jumlah untuk menilai uji kualitas suatu produk menggunakan minimal 4 hingga 5 orang panelis terlatih (Krissetiana:2015), panelis untuk uji kualitas menggunakan 7 orang panelis yang terdiri dari Dosen PKK dan Guru sedangkan untuk uji kesukaan menggunakan 30 orang panelis tidak terlatih yang terdiri dari mahasiswa dan mahasiswi di lingkungan Fakultas Teknik dan Kejuruan Undiksha
Variabel adalah objek penelitian atau apa yang menjadi titik perhatian suatu penelitian (Arikunto,2006:118). Variabel dalam penelitian ini adalah kualitas cake pisang subtitusi tepung kulit pisang kepok dilihat dari aspek aroma, tekstur, dan rasa dan tingkat kesukaan. Kualitas merupakan tingkat baik buruknya sesuatu yang dapat dinilai dari kesesuaian terhadap persyaratan produk. Kualitas cake kulit pisang kepok ini dinilai dari beberapa faktor diantaranya yaitu aroma, tekstur, dan rasa. Aroma adalah hasil respon dari indera pencium terhadap suatu produk makanan ataupun non pangan, aroma dari cake pisang ini beraroma khas kulit pisang kepok.Tekstur merupakan hasil dari suatu produk yang dapat dinilai dari peraba permukaannya baik itu kasar, keras, lembut dan halus. Tekstur dari cake pisang ini adalah butir-butiran dan poripori halus. Rasa adalah hasil dari suatu produk yang dinilai dengan indra perasa atau pengecap. Cake kulit pisang ini memiliki rasa yang khas dari tepung kulit pisang kepok dan tingkat kesukaan merupakan daya terima atau selera manusia terhadap suatu produk tertentu.

Metode yang digunakan dalam penelitian ini adalah metode observasi. Metode observasi adalah cara mengumpulkan data dengan melakukan pengamatan secara langsung terhadap objek yang diteliti menggunakan seluruh alat indera (Arikunto, 2002). Observasi digunakan untuk mengumpulkan data tentang kualitas fisik cake pisang ditinjau dari aspek aroma, tekstur, rasa. Untuk uji kualitas dari cake pisang ini digunakan uji organoleptik yang meliputi aroma, tekstur dan rasa. Penilaian organoleptik digunakan untuk meneliti mutu komoditif makanan.Uji organoletik disebut sebagai penilaian yang dilakukan dengan indera manusia atau sensorik.

Uji organoleptik yang digunakan dalam penelitian ini adalah uji mutu hedonik. Dalam uji mutu hedonik ini panelis diminta tanggapan pribadinya tentang kesan baik buruknya hasil penelitian dan menemukan tingkat mutu suatu produk yang disebut mutu skala hedonik. Panelis yang terpilih dalam penelitian ini adalah panelis terlatih 
yang berjumlah 7 orang yang akan menguji kualitas dari cake kulit pisang kepok panelis terlatih ang berjumlah orang ini terdiri dari 5 dosen PKK dan 2 orang guru SMK. Panelis menanggapi dengan cara memberikan tanda chek list $(\sqrt{ })$ sesuai dengan kriteria yang telah ditentukan pada lembar observasi panelis terhadap kualitas cake pisang yang berdasarkan tes skala mutu hedonik, data penilaian dapat ditransformasikan dalam skala numerik dan selanjutnya dapat dianalisis statistik untuk interprestasinya.

skala mutu hedonik dalam penelitian ini menggunakan rentangan sebagai berikut:

Tabel 2

Skala Mutu Hedonik Uji kualitas cake kulit pisang kapok

\begin{tabular}{cc}
\hline Skala Hedonik & $\begin{array}{c}\text { Skala } \\
\text { Numerik }\end{array}$ \\
\hline SangatBaik & 4 \\
\hline Baik & 3 \\
\hline Cukup Baik & 2 \\
\hline Tidak Baik & 1 \\
\hline Sangat Tidak Baik & 0 \\
\hline
\end{tabular}

Tabel 3

Skala mutu hedonik uji kesukaan cake kulit pisang kepok

\begin{tabular}{cc}
\hline Skala Hedonik & $\begin{array}{c}\text { Skala } \\
\text { Numerik }\end{array}$ \\
\hline Sangat Suka & 4 \\
\hline Suka & 3 \\
\hline Cukup Suka & 2 \\
\hline Tidak Suka & 1 \\
\hline Sangat Tidak Suka & 0 \\
\hline
\end{tabular}

Instrumen yang digunakan dalam penelitian ini berupa lembar uji kualitas untuk panelis terlatih yang berjumlah 7 orang yang nantinya akan diberikan pada setiap panelis untuk menilai kualitas dan untuk menilai tingkat kesukaan berjumlah 30 orangterdiri dari panelis tidak terlatih. Untuk mendapatkan hasil dan responden maka dibuat tolak ukur dan lembar uji kualitas sebagai berikut:
Tabel 4.

Tolak Ukur Uji Kualitas Cake Pisang Tepung Kulit Pisang Kepok

\begin{tabular}{|c|c|c|c|}
\hline Nilai & Aroma & Tekstur & Rasa \\
\hline 4 & $\begin{array}{l}\text { Aroma } \\
\text { khas kulit } \\
\text { pisang } \\
\text { kepok } \\
\text { sangat kuat }\end{array}$ & $\begin{array}{l}\text { Butiran } \\
\text { cake } \\
\text { sangat } \\
\text { halus dan } \\
\text { pori-pori } \\
\text { rata }\end{array}$ & $\begin{array}{l}\text { Rasa } \\
\text { khas kulit } \\
\text { pisang } \\
\text { sangat } \\
\text { terasa }\end{array}$ \\
\hline 3 & $\begin{array}{l}\text { Aroma } \\
\text { khas kulit } \\
\text { pisang } \\
\text { kepok kuat }\end{array}$ & $\begin{array}{l}\text { Butiran } \\
\text { cake } \\
\text { halus dan } \\
\text { pori-pori } \\
\text { rata }\end{array}$ & $\begin{array}{l}\text { Rasa } \\
\text { khas kulit } \\
\text { pisang } \\
\text { terasa }\end{array}$ \\
\hline 2 & $\begin{array}{l}\text { Aroma } \\
\text { khas kulit } \\
\text { pisang } \\
\text { kepok } \\
\text { cukup kuat }\end{array}$ & $\begin{array}{l}\text { Butiran } \\
\text { cake } \\
\text { cukup } \\
\text { halus dan } \\
\text { pori-pori } \\
\text { cukup } \\
\text { rata }\end{array}$ & $\begin{array}{l}\text { Rasa } \\
\text { khas kulit } \\
\text { pisang } \\
\text { cukup } \\
\text { terasa }\end{array}$ \\
\hline 1 & $\begin{array}{l}\text { Aroma } \\
\text { khas kulit } \\
\text { pisang } \\
\text { kepok tidak } \\
\text { kuat }\end{array}$ & $\begin{array}{l}\text { Butiran } \\
\text { cake tidak } \\
\text { halus dan } \\
\text { pori-pori } \\
\text { tidak rata }\end{array}$ & $\begin{array}{l}\text { Rasa } \\
\text { khas kulit } \\
\text { pisang } \\
\text { tidak } \\
\text { terasa }\end{array}$ \\
\hline 0 & $\begin{array}{l}\text { Aroma } \\
\text { khas kulit } \\
\text { pisang } \\
\text { kepok } \\
\text { sangat } \\
\text { tidak kuat }\end{array}$ & $\begin{array}{l}\text { Butiran } \\
\text { cake } \\
\text { sangat } \\
\text { tidak } \\
\text { halus dan } \\
\text { pori-pori } \\
\text { cake } \\
\text { sangat } \\
\text { tidak rata }\end{array}$ & $\begin{array}{l}\text { Rasa } \\
\text { khas kulit } \\
\text { pisang } \\
\text { tidak } \\
\text { terasa } \\
\text { sama } \\
\text { sekali }\end{array}$ \\
\hline
\end{tabular}

Tabel 5.

Tolak Ukur Uji Kesukaan Cake pisang tepung kulit pisang kepok

\begin{tabular}{cc} 
Nilai & Respon atau Tanggapan \\
\hline 4 & $\begin{array}{c}\text { Sangat Suka dengan cake kulit } \\
\text { pisang kapok }\end{array}$ \\
\hline 3 & $\begin{array}{c}\text { Suka dengan cake kulit pisang } \\
\text { kapok }\end{array}$ \\
\hline 2 & $\begin{array}{c}\text { Cukup Suka dengan cake kulit } \\
\text { pisang kapok }\end{array}$ \\
\hline
\end{tabular}




\begin{tabular}{cc}
1 & $\begin{array}{c}\text { Tidak Suka dengan cake kulit } \\
\text { pisang kapok }\end{array}$ \\
\hline 0 & $\begin{array}{c}\text { Sangat Tidak Suka dengan cake } \\
\text { kulit pisang kapok }\end{array}$ \\
\hline
\end{tabular}

Tujuan yang ingin dicapai dari penelitian ini adalah untuk mengetahui kualitas cake pisang dilihat dari aspek aroma, tekstur, dan rasa terhadap cake pisang dengan substitusi tepung kulit pisang kepok. Sesuai dengan tujuan penelitian, maka analisis relevan untuk tujuan penelitian tersebut adalah metode analis deskriptif kuantitatif. Analisis deskriptif kuantitatif yaitu penggolahan data dengan cara menyusun secara sistematis dalam bentuk angka-angka atau persentase (Arikunto, 2014).

Setelah dilakukan analisis data dengan menggunakan metode deskriptif kuantitatif terhadap data yang di uji kualitas cake pisang yang berbahan tepung kulit pisang kepok sebagai subtitusi tepung terigu, maka akan didapatkan suatu kesimpulan pada kualitas cake pisang yang dilihat dari aspek aroma, tekstur, dan rasa sesuai dengan kriteria yang digunakan yaitu sangat baik, baik, cukup baik, kurang baik, sangat tidak baik

Berikut adalah rumus yang digunakan dalam proses analisis data terhadap kualitas Cake Kulit Pisang Kepok sebagai berikut :

$$
\text { Mean }(M)=\frac{\sum X}{N}
$$

Keterangan :

$$
\begin{array}{ll}
\mathrm{M} & =\text { Mean ( rata-rata) } \\
\Sigma \mathrm{x} & =\text { Jumlah masing-masing } \\
\mathrm{N} & \text { skor (aroma, tekstur dan Rasa) } \\
& =\text { Jumlah (sampel). }
\end{array}
$$

Rumus pedoman konversi dengan skala 5 (Lima) :

$$
\begin{aligned}
& M+1,5 \mathrm{SD} \longrightarrow M+3,0 \mathrm{SD} \\
& M+0,5 \mathrm{SD} \longrightarrow \mathrm{M}+1,5 \mathrm{SD} \\
& M-0,5 \mathrm{SD} \longrightarrow \mathrm{M}+0,5 \mathrm{SD}
\end{aligned}
$$

$$
\begin{array}{ll}
M-1,5 \mathrm{SD} & \longrightarrow \mathrm{M}-0,5 \mathrm{SD} \\
\mathrm{M}-3,0 \mathrm{SD} & \longrightarrow \mathrm{M}-1,5 \mathrm{SD}
\end{array}
$$

Keterangan Rumus :

$\mathrm{M} \quad=$ Mean ( rata tengah)

$\mathrm{SD}=$ Standar Deviasi

(Koyan, 2011).

Keterangan :

$\mathrm{M}=$ Mean atau rata-rata dengan rumus :

$M=\frac{1}{2} \times($ Skor Maksimun + Skor Minimum $)$

SD = Standar Deviasi dicari dengan

rumus :

$\mathrm{SD}=\frac{1}{6} \times($ Skor Maksimum - Skor

Minimum)

Skor Maksimum $\quad=4$

Skor Minimum $\quad=0$

Berdasarkan rumus diatas, untuk mencari konversi data yang telahterkumpul sehingga memperoleh hasil adalah dengan cara sebagai berikut : $\mathrm{M}=\frac{1}{2} \times($ Skor Maksimun + Skor Minimum) $\mathrm{M}=\frac{1}{2} \times(4+0)$

$\mathrm{M}=2$

$\mathrm{SD}=\frac{1}{6} \times$ ( Skor Maksimum - Skor Minimum)

$\mathrm{SD}=\frac{1}{6} \times(4-0)$

$\mathrm{SD}=0,6$

Acuan pengambilan keputusan yang digunakan untuk menentukan sifat fisikdan tingkat kesukaan cake pisang ini dari aspek aroma, tekstur dan rasa berdasarkan rumus pedoman konversi dengan skala 5 (lima) sebagai berikut:

Tabel 6.

Acuan Penentu Sifat Fisik Cake Kulit Pisang Kepok

\begin{tabular}{ccc}
\hline $\begin{array}{c}\text { Rumus konversi } \\
\text { skala 5 }\end{array}$ & $\begin{array}{c}\text { Acuan } \\
\text { pengambilan } \\
\text { keputusan }\end{array}$ & Kategori \\
\hline $\begin{array}{c}M+1,5 \text { SD- } \\
M+3,0 \text { SD }\end{array}$ & $2,9 \rightarrow 3,8$ & $\begin{array}{c}\text { Sangat } \\
\text { Baik }\end{array}$ \\
\hline $\begin{array}{c}M+0,5 \text { SD- } \\
M+1,5 \text { SD }\end{array}$ & $2,3 \rightarrow 2,9$ & Baik \\
\hline $\begin{array}{c}M-0,5 \text { SD- } \\
M+0,5 \text { SD }\end{array}$ & $1,7 \rightarrow 2,3$ & Cukup \\
\hline
\end{tabular}


Jurnal Bosaparis: Pendidikan Kesejahteraan Keluarga

Volume 10, Nomor 1, Maret 2019

\begin{tabular}{ccc}
\hline $\begin{array}{c}M-1,5 \text { SD- } \\
M-0,5 \text { SD }\end{array}$ & $1,1 \rightarrow 1,7$ & $\begin{array}{c}\text { Tidak } \\
\text { Baik }\end{array}$ \\
\hline$M-3,0$ SD- & $0,2 \rightarrow 1,1$ & $\begin{array}{c}\text { Sangat } \\
\text { Tidak } \\
\text { Baik }\end{array}$ \\
\hline
\end{tabular}

Tabel 7.

Acuan Penentu Tingkat Kesukaan Cake Kulit Pisang Kepok

\begin{tabular}{|c|c|c|}
\hline $\begin{array}{c}\text { Rumus konversi } \\
\text { skala } 5\end{array}$ & $\begin{array}{c}\text { Acuan } \\
\text { pengambilan } \\
\text { keputusan }\end{array}$ & Kategori \\
\hline $\begin{array}{l}M+1,5 \text { SD- } \\
M+3,0 \text { SD }\end{array}$ & $2,9 \rightarrow 3,8$ & $\begin{array}{c}\text { Sangat } \\
\text { Suka }\end{array}$ \\
\hline $\begin{array}{l}M+0,5 \text { SD- } \\
M+1,5 \text { SD }\end{array}$ & $2,3 \rightarrow 2,9$ & Suka \\
\hline $\begin{array}{l}M-0,5 \text { SD- } \\
M+0,5 S D\end{array}$ & $1,7 \rightarrow 2,3$ & $\begin{array}{l}\text { Cukup } \\
\text { Suka }\end{array}$ \\
\hline $\begin{array}{l}M-1,5 \text { SD- } \\
M-0,5 \text { SD }\end{array}$ & $1,1 \rightarrow 1,7$ & $\begin{array}{l}\text { Tidak } \\
\text { Suka }\end{array}$ \\
\hline $\begin{array}{l}M-3,0 \text { SD- } \\
M-1,5 \text { SD }\end{array}$ & $0,2 \rightarrow 1,1$ & $\begin{array}{c}\text { Sangat } \\
\text { Tidak } \\
\text { Suka }\end{array}$ \\
\hline
\end{tabular}

Hasil dari penelitian ini adalah uji kualitas cake tepung kulit pisang kepok dilihat dari sifat fisik yang terdiri dari aspek aroma, tekstur, rasa. Penelis yang digunakan adalah panelis pencicip terbatas yang berjumlah 7 orang panelis terlatih yang terdiri dari 5 orang dosen 2 orang guru SMK talah menguji kualitas cake kulit pisang kepok. Data yang diperoleh kemudian di analisis menggunakan teknik analisis deskriptif kualitatif dan kuantitatif, sehingga diperoleh kesimpulan pada uji kualitas cake pisang dengan substitusi tepung kulit pisang kepok. Kualitas cake pisang dengan substitusi tepung kulit pisang kepok dilihat dari aspek aroma tekstur dan rasa dengan menggunakan 5 tingkatan skala mutu hedonik dengan katagori sangat baik, baik, cukup baik, kurang baik dan sangat tidak baik.

Hasil dari penelitian ini adalah tingkat kesukaan pada cake kulit pisang kepok, Penelis yang digunakan adalah panelis pencicip terbatas yang berjumlah 30 orang panelis yang terdiri dari mahasiswa dan mahasiswi dengan berbagai jurusan yang berada di lingkungan Fakultas Teknik dan Kejuruan. Data yang diperoleh kemudian di analisis menggunakan teknik analisis deskriptif kualitatif dan kuantitatif, sehingga diperoleh kesimpulan pada uji kesukaan pada cake pisang dengan substitusi tepung kulit pisang kepok.Pada tingkat kesukaan atau daya terima terhadap cake pisang dengan substitusi tepung kulit pisang kepok juga menggunakan 5 tingkatan skala mutu hedonik dengan kategori sangat suka, suka, cukup suka, tidak suka dan sangat tidak suka.

Hasil uji panelis terhadap kualitas dan uji tingkat kesukaandapat dilihat melalui perhitungan data berikut

1. Kualitas cake pisang dari aspek aroma.

$$
\begin{aligned}
& \text { Mean }(M)=\frac{\sum X}{N} \\
& \text { Mean }(M)=\frac{27}{7} \\
& \text { Mean }(M)=3,8
\end{aligned}
$$

2. Kualitas cake pisang dari aspek tekstur.

$$
\begin{aligned}
& \text { Mean }(M)=\frac{\sum X}{N} \\
& \text { Mean }(M)=\frac{27}{7} \\
& \text { Mean }(M)=\underline{3,8}
\end{aligned}
$$

3. Kualitas cake pisang dari aspek rasa.

$$
\begin{aligned}
& \text { Mean }(M)=\frac{\sum X}{N} \\
& \text { Mean }(M)=\frac{27}{7} \\
& \text { Mean }(M)=\underline{3,8}
\end{aligned}
$$

perhitungan uji kesukaan cake pisang substitusi tepung kulit pisang kepok adalah sebagai berikut:

$$
\text { Mean }(M)=\frac{\sum X}{N}
$$


Jurnal Bosaparis: Pendidikan Kesejahteraan Keluarga

Volume 10, Nomor 1, Maret 2019

$$
\begin{aligned}
& \text { Mean }(M)=\frac{116}{30} \\
& \text { Mean }(M)=3,8
\end{aligned}
$$

Berdasarkan hasil perhitungan dari uji kualitas atau sifat fisik cake pisang substitusi tepung kulit pisang kepok menyatakan kualitas cake pisang substitusi dilihat dari siat fisik aroma memperoleh skor 3,8 berada pada kategori sangat baik sesuai dengan tolak ukur yaitu aroma kulit pisnag kepok pada cake pisang tersebut sangat kuat. Sifat fisik dari segi tekstur cake pisang substitusi tepung kulit pisang kepok memperoleh skor 3,8 berada pada kategori sangat baik sesuai tolak ukur yaitu butiran cake sangat halus dan poripori sangat rata. Sifat fisik dari segi rasa cake pisang substitusi tepung kulit pisang kepok memperoleh skor 3,8 berada pada kategori sangat baik dengan tolak ukur yaitu rasa khas kulit pisang kepok sangat terasa.

Berdasarkan hasil perhitungan dari hasil uji kesukaan cake pisang substitusi tepung kulit pisang kepok menyatakan tingkat kesukaan cake pisang substisusi tepung kulit pisang kepok memperoleh skor 3,8 berada pada kategori sangat suka dengan tolak ukur yaitu sangat suka.

Hasil uji kualitas dan uji kesukaan cake pisang substitusi tepung kulit pisang kepok dapat dilihat pada diagram batang sebagai

berikut:

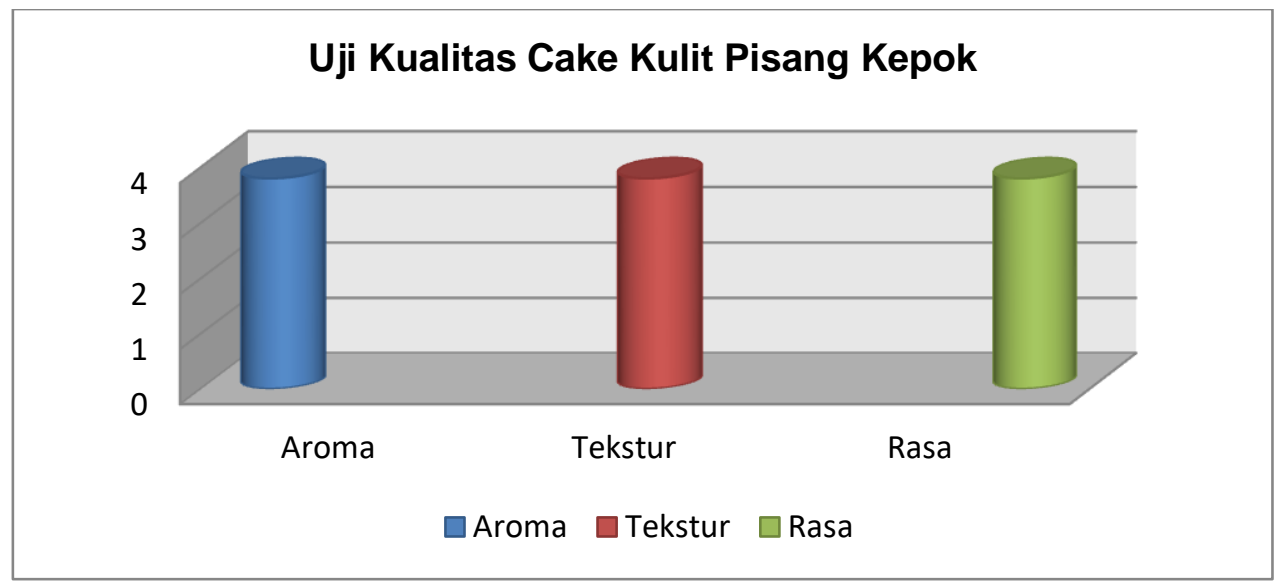

Diagram batang 01. Hasil uji kualitas cake kulit pisang kepok

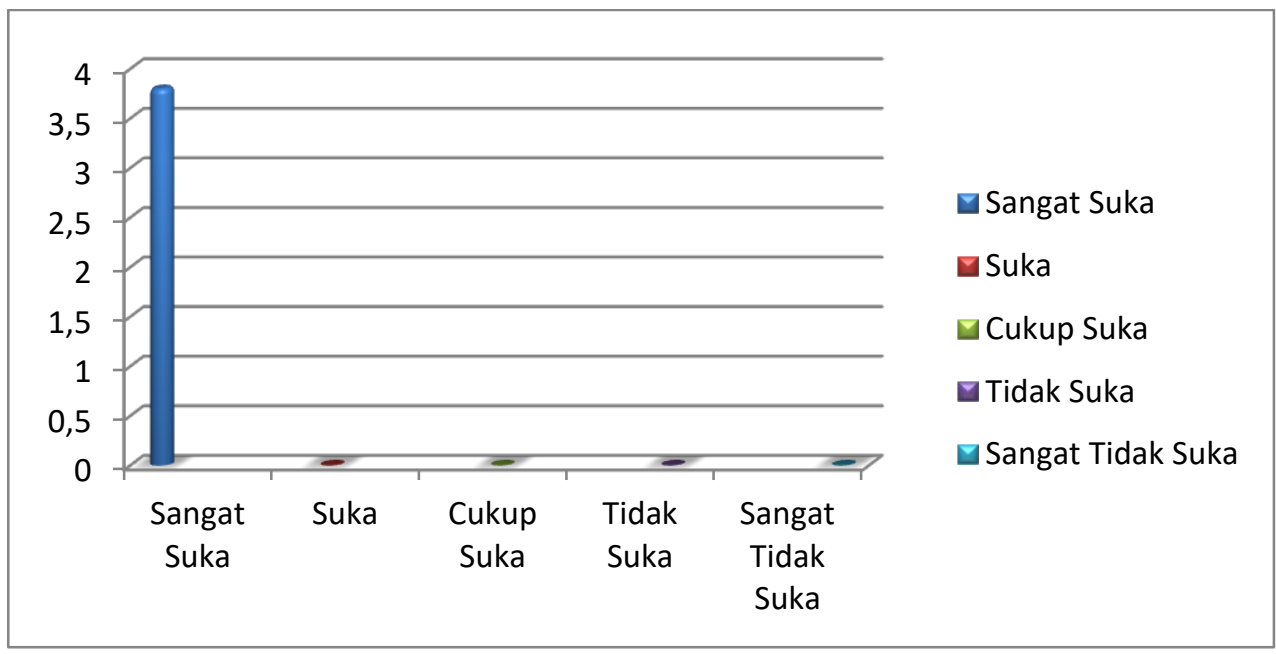




\section{Diagram batang 02 . Hasil uji kesukaan cake kulit piang kepok}

Hasil uji kualitas fisik cake pisang substitusi tepung kulit pisang kepok yaitu dari segi aroma, tekstur dan rasa yang diperoleh 7 panelis terlatih memperoleh skor rata-rata sebesar 3,8 termasuk dalam kategori sangat baik.

a. Sifat fisik cake pisang substitusi tepung kulit pisang kepok dari aspek aroma

Aroma merupakan hasil respon terhadap suatu produk yang dapat dinilai dengan bantuan indra penciuman yaitu hidung. Aroma dari suatu makanan merupakan salah satu komponen yang mempengaruhi daya tarik minat konsumen terhadap suatu produk tersebut. Ditinjau dari kualitas aroma cake yang baik, cake pisang substitusi tepung kulit pisang kepok berada pada kategori sangat baik dengan perolehan skor 3,8 dan sesuai dengan tolak ukur yang ditentukan yaitu aroma dari kulit pisang kepok sangat kuat hal ini menjadi ciri khas dari produk cake dengan substitusi tepung pisang kepok.

b. Sifat fisik cake pisang substitusi tepung kulit pisang kepok dari aspek tekstur

Tekstur merupakan nilai raba pada suatu permukaan baik itu kasar, halus, lembut dan keras pada suatu produk.Tekstur dari suatu produk merupakan salah satu komponen yang mempengaruhi tampilan produk. Ditinjau dari kualitas tekstur cake yang baik, cake pisang substitusi tepung kulit pisang kepok berada pada kategori sangat baik dengan perolehan skor 3,8 dan sesuai dengan tolak ukur yaitu butiran cake halus dan pori-pori rata.

c. Sifat fisik cake pisang substitusi tepung kulit pisang kepok dari aspek rasa

Rasa merupakan kombinasi mutlak dari dua unsur yaitu rasa dan aroma, rasa yang diinginkan harus sesuai dengan aroma yang diinginkan. Ditinjau dari kualitas rasa cake yang baik, cake kulit pisang kepok berada pada kategori sangat baik dengan perolehan skor 3,8 dan sesuai dengan tolak ukur yaitu rasa khas kulit pisang kepok sangat terasa.
Dan hasil dari tingkat kesukaan terhadap cake substitusi tepung kulit pisang kepok yang diperoleh dari 30 panelis tidak terlatih yang diambil dari mahasiswa yang berada di lingkungan Fakultas Teknik dan Kejuruan memperoleh skor rata-rata sebesar 3,8 tergolong dalam kategori Sangat Suka. Tingkat kesukaan merupakan daya terima atau ketertarikan pada suatu produk. hasil dari daya terima yang dilakukan dilingkungan Fakultas Teknik dan Kejuruan Undiksha menggunakan 30 panelis yang terdiri dari mahasiswa dan mahasiswi memperoleh skor rata-rata 3,8 dan sesuai dengan tolak ukur yaitu tingkat kesukaan atau daya terima produk cake pisang substitusi tepung kulit pisang kepok dapat diterima dengan sangat baik. Adapun masukan dari beberapa panelis yaitu menambahkan toping dan harus memberikan label pada produk tersebut.

\section{SIMPULAN}

1. Berdasarkan hasil uji kualitas fisik cake pisang substitusi tepung kulit pisang kepok yaitu aroma, tekstur dan rasa yang diperoleh dari 7 panelis terlatih memperoleh skor 3,8 termasuk dalam kategori sangat baik. Ditinjau dari kualitas aroma cake yang baik, cake pisang substitusi tepung kulit pisang kepok berada pada kategori sangat baik dengan perolehan skor 3,8 dan sesuai dengan tolak ukur yang ditentukan yaitu aroma dari kulit pisang kepok sangat kuat hal ini menjadi ciri khas dari produk cake dengan substitusi tepung pisang kepok. Ditinjau dari kualitas tekstur cake yang baik, cake pisang substitusi tepung kulit pisang kepok berada pada kategori sangat baik dengan perolehan skor 3,8 dan sesuai dengan tolak ukur yaitu butiran cake halus dan pori-pori rata. Ditinjau dari kualitas cake yang baik, rasa cake substitusi tepung kulit pisang kepok berada pada kategori sangat baik dengan perolehan skor 3,8 dan sesuai dengan tolak ukur yaitu rasa khas kulit pisang kepok sangat terasa. 
2. Berdasarkan hasil uji kesukaan cake kulit pisang kepok yaitu memperoleh skor rata-rata 3,8 dari 30 panelis tidak terlatih yang terdiri dari mahasiswa dan mahasiswi berbagai jurusan di lingkungan Fakultas Teknik dan Kejuruan termasuk dalam kategori sangat suka, menandakan bahwa cake kulit pisang kepok dapat diterima oleh banyak orang.

\section{SARAN}

1. Tepung kulit pisang kepok memiliki kandungan gizi yang baik, salah satu kandungan yang banyak terkandung adalah vitamin $\mathrm{C}$, dengan salah satu kandungan gizi tersebut diharapkan dapat dimanfaatkan dengan baik agar kulit pisang kepok yang biasanya hanya dibuang begitu saja dapat diolah

2. Limbah kulit pisang kepok mudah didapat sehingga dapat dijadikan sebagai produk dalam industri rumah tangga.

\section{DAFTAR RUJUKAN}

Arfinindya, Rindang. 2015. “ Pengaruh Proporsi Tepung Komposit dan dan Proporsi Shortening Terhadap Hasil Jadi Kulit Pie". Universitas Negeri Surabaya.Volume 4. Nomor 1 (hlm. 126-127)

Arikunto, Suharsimi. 2002. Prosedur Penelitian Suatu Pendekatan Praktek. Jakarta: PT Rineka Cipta.

Ariani, Risa P. 2018. Preservasi Makanan Lokal. Depok: PT.Raja Grafindo Persada

Astawan, Made. "Pengertian Susu" Tersedia pada https://www.scribd.com/document/2 4606395/Susu. 19 april 2018 (10:30).

Bahalwan, F. 2011. Fungsi Bahan-Bahan Yang Digunakan Dalam PembuatanCake. http://writecooklove.blogspot.co.id/2 011_01_01_archive.html. 07 februari $201 \overline{8}(1 \overline{1}: 09)$.
Cornelia, Pary, dkk. 2016. "Analisis Kandungan Gizi Kulit Pisang Kepok Sebagai Bahan Baku Krupuk". Institut Agama Islam Negeri Ambon.Volume 5.Nomor 1. (hlm. 119-120)

Hastuti, Ningrum Dwi. 2017. "Kajian Variasi Penambahan Tepung Terigu Dan Penambahan Air Pada Pembuatan Donat Dari Limbah Kulit Pisang Kepok". Politeknik Negeri Pontianak.Volume 8.Nomor 1. (hlm.57-58)

Gulendra, I Wayan."Pengertian Warna dan Tekstur" Tersedia pada http://www.google.co.id /warna/tekstur/html.

Julfan, dkk. 2016."Pemanfaatan Kulit Pisang Kepok (Musa Paradisiaca Linn) Dalam Pembuatan Dodol". Universitas Riau. Volume 3.Nomor 2. (hlm.6-7)

Jurlan, Herlembang. 2016. Dimensi Kualitas Makanan. Yogyakarta: PT. Kanisius.

Krissetiana, Henny. 2015. Uji Organoleptik Bahan Pangan. Yogyakarta: PT. Citra Aji Parama

Koyan, Wayan. 2012. Statistik Pendidikan Teknik Analisia Data Kuantitatif. Singaraja: Universitas Pendidikan Ganesha.

Marlen, Herdiyanto dan Sarifah Hudaya.2009. Teknologi Pengolahan Roti danKue.Bandung: Widya Padjajaran.

Munadjim. 2014. Teknologi Pengolahan Pisang. Jakarta: PT Gramedia Jakarta

Rayner, Tintin. 2017. Simple And Moist Cake. Jakarta: PT Samarinda Utama

Soekarto, S.T. 1985. Penilain Organoleptik. Jakarta: Bhatara Karya Aksara.

Surianis, Luh. 2015. Uji Kualitas Rasa Manis Pada Chiffon Cake Tepung 
Jurnal Bosaparis: Pendidikan Kesejahteraan Keluarga

Volume 10, Nomor 1, Maret 2019

Ubi Jalar Kuning. Universitas Pendidikan Ganesha. Vol.3, No 1.

Suartini, Katut. 2017. Pemanfaatan Tepung Pisang Kepok Menjadi Kulit Pie. Universitas Pendidikan Ganesha. Vol.8, No 2.

Novitasari, Ni Luh Ayu. 2017. Studi Eksperimen Pengolahan Kue Semprit Berbahan Baku Tepung Kulit Pisang Kepok. Universitas Pendidikan Ganesha. Vol.8.No.2 (2017).

Tjitrosoepomo. 2011. "Jenis-jenis Pisang dan Kegunaannya". Jakarta: PT. Dinastindo Adiperkasa

Widanti, Yannie Asri. 2015. "Karakteristik Organoleptik Brownies Dengan Campuran Tepung Mocaf dan Tepung Ketan Hitam Dengan Variasi Lama Pemanggangan". Universitas Slamet Riadi Surakarta.Volume 27.Nomor 2. 